\title{
COMPOSITION AND DISCRIMINATION OF SANDSTONES: A STATISTICAL EVALUATION OF DIFFERENT ANALYTICAL METHODS
}

\author{
HILMAR VON EYNATTEN ${ }^{1}$, CARLES BARCELÓ-VIDAL ${ }^{2}$, AND VERA PAWLOWSKY-GLAHN ${ }^{2}$ \\ ${ }^{1}$ Institut für Geowissenschaften, FSU Jena, Burgweg 11, D-07749 Jena, Germany \\ ${ }^{2}$ Departament d'Informàtica i Matemàtica Aplicada, Universitat de Girona, Lluis Santaló, s/n, E-17071 Girona, Spain \\ e-mail: eynatten@geo.uni-jena.de
}

\begin{abstract}
The discriminative power of four analytical approaches to sandstone composition is evaluated with respect to the separation of different formations and source areas. The case study is Cretaceous synorogenic sandstones (litharenites) from the Eastern Alps of Europe, which belong to four different formations and are derived from two source areas. Methods evaluated are light-mineral analysis (petrographic framework composition), heavy-mineral analysis, major-element XRF analysis, and trace-element XRF analysis. The statistical parameters calculated (percentages of well-classified samples, Mahalanobis distance) applying the logratio approach suggest that light-mineral analysis has a significantly lower discriminative power than the other three methods. Taking into account the analytical expenditure for data acquisition, trace-element analysis appears to be the most efficient method for discrimination of at least the sandstone units examined. Although based on a single case study, these results are interpreted to have a more general meaning with respect to sandstone discrimination based on composition. Concerning sandstone provenance, trace-element analysis provides a quick tool to estimate the discriminative potential of a sample suite, i.e., the potential to discriminate between contrasting source areas. If a provenance model already exists and discriminate functions between contrasting source areas are calculated, trace-element analysis is considered to be most efficient in correctly assigning an unknown sample to its source area. These results cannot be extended to all kinds of sands and sandstones, but they cast serious doubt on the belief that petrographic point-count methods are the best approach to discriminate between sandstones.
\end{abstract}

\section{INTRODUCTION}

The complex topic of sandstone composition is treated in the literature in several different ways concerning both analytical techniques and lines of interpretation. Interpreting the composition of sandstones in terms of, for example, their belonging to different lithologic units (e.g., Füchtbauer 1964), their derivation from different sources on both global (e.g., Potter 1978; Dickinson and Suczek 1979) and regional scale (e.g., van de Kamp and Leake 1995), as well as contrasting climatic (e.g., Suttner et al. 1981) or diagenetic (e.g., Milliken 1988) conditions requires the confirmation that these sandstones display significant differences in composition.

The composition of sandstones can be ascertained in two fundamental ways: petrographically (mineralogy and texture) or chemically. The petrographic composition of sandstones generally is obtained by analyzing their framework components using point-count techniques on thin sections (e.g., Ingersoll et al. 1984). We refer to this method as light-mineral analysis, in contrast to heavy-mineral analysis. The latter constitutes a small fraction (mathematically: subcomposition) of the whole-rock mineralogical composition, but is usually treated separately because the data are obtained by different analytical methods (e.g., Morton 1985). Point-count methods on thin sections allow us to differentiate between primary detrital grains and secondary diagenetic processes, e.g., authigenic phases and compaction.

The chemical composition of sandstones provides whole-rock data. Accordingly, they do not allow a differentiation between detrital or diagenetic origin of certain elements. XRF analysis of a powdered rock specimen is the most widely applied analytical technique in the determination of the major-element and trace-element chemistry of rocks (Rollinson 1993). Major-element and trace-element analysis are here treated separately because they are performed using partly different analytical methods. Trace-element data constitute a small fraction of the whole-rock chemical composition.

Apart from cases in which one component is absolutely missing for one sample group or the separation of groups is obvious because of very large differences, the determination of significant differences between sandstone compositions requires statistical analysis. All data mentioned are compositional data, which means that they are proportions, subjected to the constant-sum constraint, and therefore should not be analyzed by standard statistical methods (Aitchison 1986). Special techniques are necessary to rigorously analyze compositional data, and several studies have already demonstrated their usefulness (e.g., Butler and Woronow 1986; Rollinson 1992; Heins 1993; Cardenas et al. 1996; Weltje et al. 1996; Barceló-Vidal et al. 1997).

The aim of this paper is to evaluate the discriminative power of four different analytical approaches (light-mineral and heavy-mineral analysis and major-element and trace-element analysis) to the composition of sandstones and relate the outcome to the analytical expenditure involved with each method. The case study is a well-documented example of synorogenic Cretaceous sandstones from the Northern Calcareous Alps in Austria (von Eynatten et al. 1996; von Eynatten and Gaupp 1999). The applied statistical methods take into account the specific nature of compositional data. Although based on a single case study, the results are interpreted to have a more general meaning with respect to the discrimination of sandstones based on composition, with special emphasis on provenance discrimination.

\section{CASE STUDY}

\section{Geological Setting}

The case study used in this paper is Cretaceous synorogenic sandstones from the Northern Calcareous Alps in Austria (Fig. 1A). The Cretaceous orogeny of the Alps documents the early stages of convergence between Africa-derived plates (Adriatic plate, Austroalpine microplate) and the European plate, which were separated since the Early to Middle Jurassic by the Penninic ocean (Fig. 1B). Ongoing convergence led to subduction of Penninic oceanic crust in the Late Cretaceous and a final continent-continent collision in the Eocene (e.g., Froitzheim et al. 1996). In the Northern Calcareous Alps (belonging to the Upper Austroalpine unit) the Cretaceous is characterized by the formation of various nappes which were thrusted onto each other top-to-the-northwest. Thrusting started in the southeast in the latest Jurassic and subsequently propagated towards the northwest (Fig. 2).

The sandstones under investigation were deposited by turbidity currents in elongated basins situated on individual nappes, with depositional axes striking parallel to nappe fronts (piggy-back basins, cf. Ori and Friend 1984). Two source areas were distinguished in a previous study (von Eynatten and Gaupp 1999): the first is situated to the southeast, the second to the northwest of the depositional sites (Fig. 2). Both source areas were found to be composed largely of Paleozoic metasediments, Mesozoic carbonates, and ultrabasic rocks, but the relative contribution of each of these source rocks varied with time and between the two source areas. A distinct 


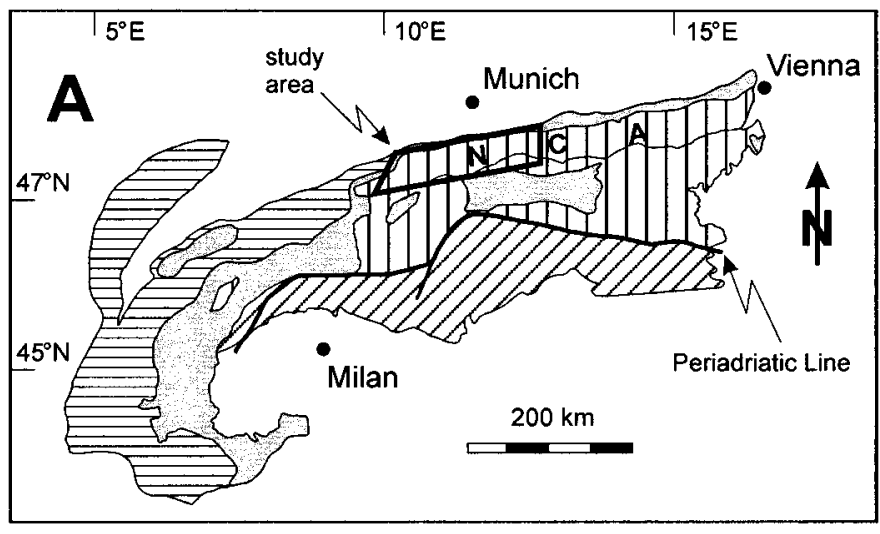

Helvetic (European plate)

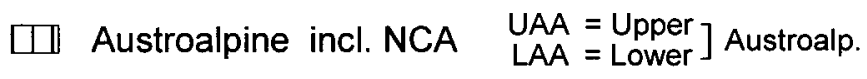
$\square$ Southalpine (Adriatic plate) $\triangle \nabla$ Tisza

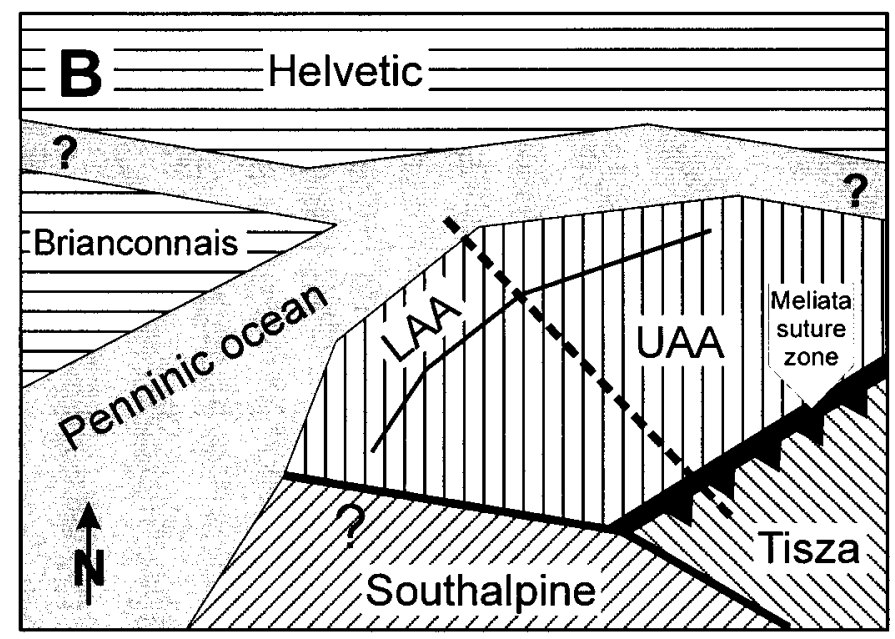

Fig. 1.-A) Structural sketch map of the European Alps with location of the study area in the Northern Calcareous Alps (NCA). B) Paleographic sketch showing positions of major structural units at around Valaginian to Hauterivian time, 140-130 Ma (modified after Froitzheim et al. 1996, von Eynatten and Gaupp 1999). Stippled line indicates position of cross sections from Figure 2. The present-day Northern Calcareous Alps form the Upper Austroalpine (UAA) sedimentary cover, which was thrusted over Lower Austroalpine (LAA) and Penninic units in Late Cretaceous to Tertiary time.

difference between the two source areas is the exclusive occurrence of highpressure metamorphic rocks in the northwestern source area, as evidenced by the chemistry of detrital blue amphiboles (glaucophane) and white mica (phengite) in sandstones derived from this source (von Eynatten and Gaupp 1999). Rare blue amphiboles in sandstones derived from the southeastern source area are chemically different in composition (crossite to riebeckite) and white micas are exclusively muscovites (von Eynatten and Gaupp 1999).

The sandstones belong to four formations ranging in age from Valanginian to Santonian (Fig. 3): the Rossfeld and Lech formations, which were derived from the southeastern source area, and the Losenstein and Branderfleck formations, which were derived from the northwestern source area (Fig. 2). Macroscopically these sandstones often are quite similar, and their regional distribution is obscured because of complicated tectonics in the present-day nappe pile. On the other hand, these sandstones are important recorders of Cretaceous synsedimentary tectonics (e.g., Gaupp 1982; Faupl and Wagreich 1992). Thus, a quick tool is required to assign a given sandstone of ambiguous origin to its correct stratigraphic formation and source area.

All of the sandstone formations are affected by postsedimentary nappe tectonics, including faulting, folding, and, sometimes, boudinage of competent sandstone layers. On microscopic scales this deformation is reflected in considerable compaction and squeezing of soft lithoclasts. Illitization and chloritization of fine-grained lithoclasts is also a commonly observed feature (von Eynatten 1996). Calcite cements are derived from dissolution of carbonate clasts and reprecipitation. Data on vitrinite reflectance and illite crystallinity indicate that temperatures during the burial stage of the sandstones did not exceed $150-200^{\circ} \mathrm{C}$ (e.g., Gaupp and Batten 1985). The thermal overprint increases from northwest to southeast. Because of the considerable diagenetic overprint, identification of individual grain types cannot be as sophisticated as in sands and sandstones that were not affected or only little affected, by diagenetic processes.

\section{Sandstone Composition}

From the Cretaceous sandstones described above a set of 52 sandstones is available, which were analyzed by all of the four analytical methods.

On the basis of light-mineral data, all of the samples are classified as litharenites following classifications of Zuffa (1980) and McBride (1963) (von Eynatten and Gaupp 1999). The QmFLt diagram (Fig. 4) illustrates the predominance of lithoclasts and the relatively low amounts of feldspars, which range from 0.3 to $5.3 \%$. Lithoclasts commonly include carbonate extrabasinal clasts (21.7-75.3\%), subdivided into dolomite (D), micritic calcite $(\mathrm{Cm})$ and sparry calcite $(\mathrm{Cs})$, and silicate lithoclasts such as metasedimentary clasts (Lsm, 0.7-22.0\%) and serpentinite clasts (Lu, 0.0$31.7 \%$ ). The latter are an important characteristic of these successions in terms of both variability and source-rock information. The occurrence of serpentinite clasts is related to common chrome spinel in heavy-mineral composition (von Eynatten et al. 1997). Other quartzose framework grains are chert (Qc, 2.3-39.0\%), polycrystalline quartz (Qp, 0.0-24.0\%), and monocrystalline quartz $(\mathrm{Qm}, 1.0-24.7 \%)$. Minor constituents are volcanic lithoclasts, sedimentary intraclasts, mica, chlorite, glauconite, and heavy minerals.

A better separation of formations based on light-mineral data compared to the QmFLt-diagram is obtained by using ratios of various lithoclasts in a logratio diagram (Fig. 5). Relative contributions of serpentinite (Lu), metasedimentary lithoclasts (Lsm), and dolomite (D) suggest that both source areas show considerable changes in the relative contribution of individual source rocks with time. For the southeastern source area the data reflect on average decreasing Lu/Lsm ratios from the Rossfeld Formation to the Lech Formation, suggesting a lower relative contribution of ultrabasic source rocks to the younger Lech sandstones. For the northwestern source area the data reflect on average increasing $\mathrm{D} / \mathrm{Qm}$ and $\mathrm{Lu} / \mathrm{Lsm}$ ratios from the Losenstein Formation to the Branderfleck Formation, suggesting a higher relative contribution of dolomite and ultrabasic source rocks to the younger Branderfleck sandstones (Fig. 5; see also von Eynatten and Gaupp 1999).

Using the chemical classification scheme of Herron (1988) the samples are classified as litharenites, wackes, Fe-sandstones, and sublitharenites (Fig. 6). Sandstones from the Branderfleck and Losenstein formations are mostly litharenites and wackes, whereas sandstones from the Rossfeld and Lech formations are mostly Fe-sandstones. This differentation is due to higher $\mathrm{Fe}_{2} \mathrm{O}_{3} / \mathrm{K}_{2} \mathrm{O}$ ratios for sandstones from the latter two formations. These higher ratios are due largely to lower $\mathrm{K}_{2} \mathrm{O}$ contents of these sandstones compared to sandstones from the Branderfleck and Losenstein formations. Sandstones from the Rossfeld Formation also are characterized by higher $\mathrm{SiO}_{2} / \mathrm{Al}_{2} \mathrm{O}_{3}$ ratios on average. 
NW

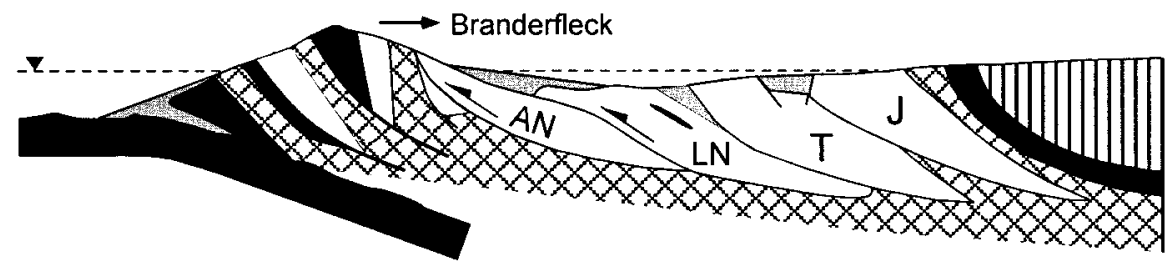

Turonian - Coniacian (90 - $85 \mathrm{Ma}$ )
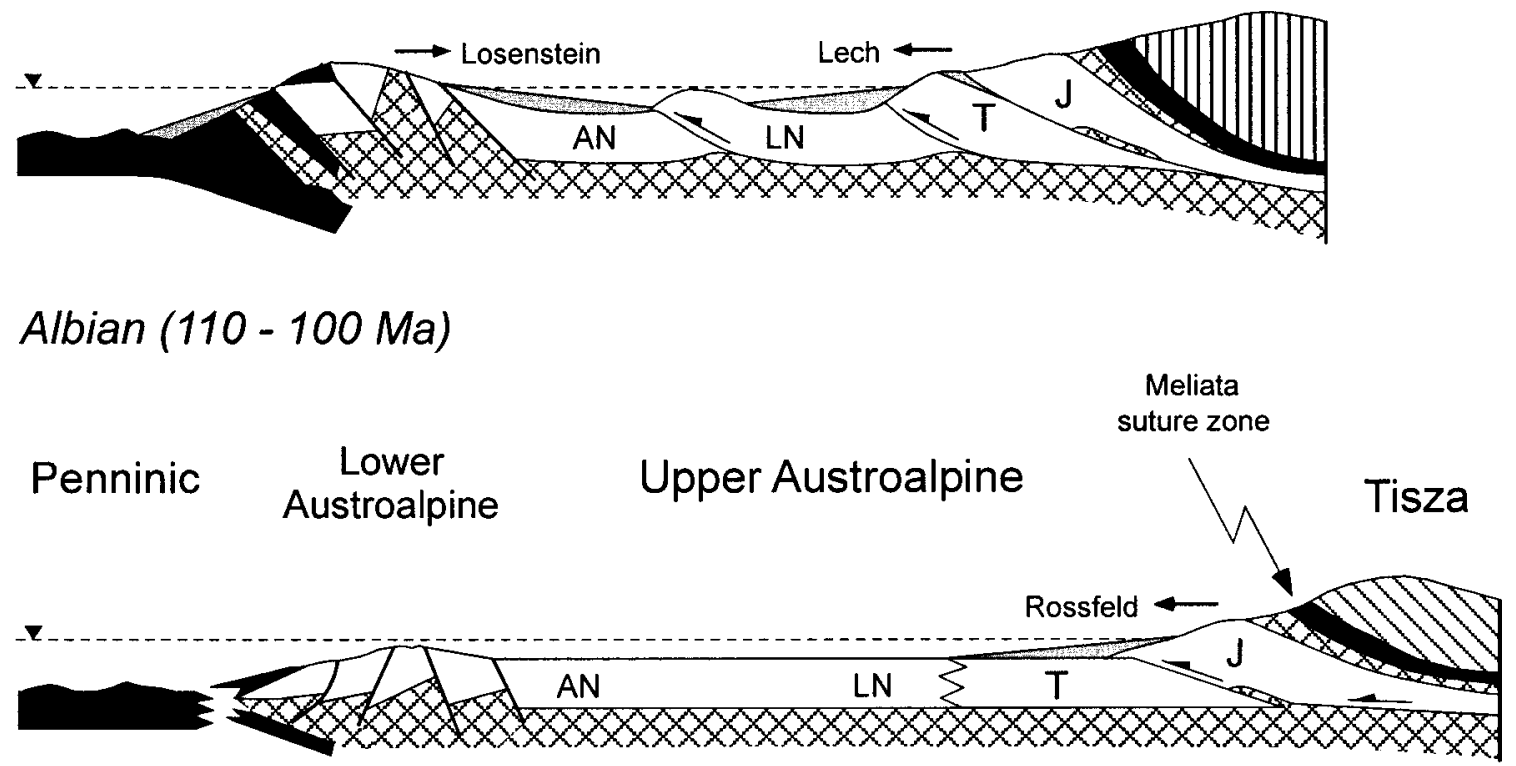

Valanginian - Hauterivian (140 - $130 \mathrm{Ma})$

\section{Austroalpine microplate:}

\section{Mesozoic (individual nappes AN, LN, T, and J)}

$\bigotimes$ Paleozoic metasediments and basement rocks oceanic crust (Penninic, Meliata)

Cretaceous siliciclastics

FIG. 2.-Tectonosedimentary model of Valanginian to Coniacian sedimentation in the Northern Calcareous Alps (modified from von Eynatten and Gaupp 1999) illustrated in three NW-SE oriented cross sections. For approximate position of cross sections see stippled line in the paleogeographic sketch of Figure 1B. Sandstones from Rossfeld and Lech formations were derived from the southeastern source area, sandstones from Losenstein and Branderfleck formations were derived from the northwestern source area.

\section{METHODS}

\section{Analytical Methods}

In this section we give a brief description of the methods used for data acquisition. For further information on the mineralogical data (details of methodology and data tables), see von Eynatten and Gaupp (1999). Tables of the chemical data are available in JSR's digital archive (see Acknowledgments). The measured variables obtained by each of the four methods are listed in Table 1 . The methods are ordered by decreasing analytical expenditure, starting with heavy-mineral analysis and ending up with traceelement XRF analysis.
Heavy-Mineral Data.-Sandstones were disaggregated using acetic acid to remove carbonate cement. Heavy minerals were obtained from the 63 $125 \mu \mathrm{m}$ sieve fraction of the disintegrated sand by gravity settling in tribromoethane. At least 200 non-opaque non-micaceous minerals were counted using the ribbon counting method (Mange and Maurer 1991; Morton and Hallsworth 1994), except for four samples from which only 100 grains were counted because of very high amounts of opaque heavy minerals.

Light-Mineral Data.-Light-mineral data were obtained by point counting of at least 300 framework grains. Thin sections were stained with Alizarin red $\mathrm{S}$ for distinguishing between calcite and dolomite. In contrast to the Gazzi-Dickinson method, minerals $>63 \mu \mathrm{m}$ within lithoclasts were 


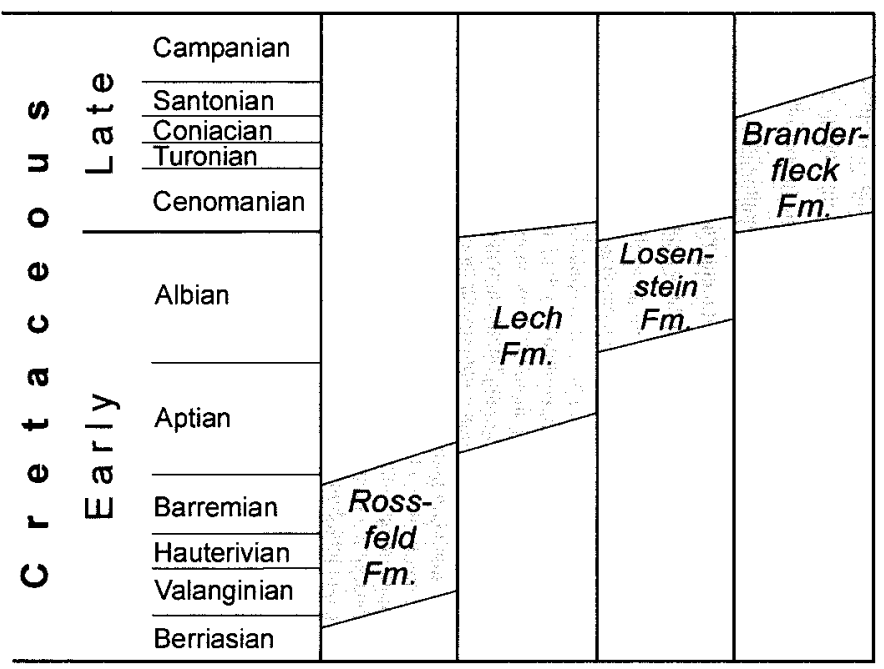

FIG. 3.-Stratigraphic range of sandstones from the four sedimentary successions.

counted as the type of lithoclast in which they occur (e.g., Decker and Helmold 1985). Monomineralic grains and lithoclasts were distinguished using the 0\% cutoff proposed by Ingersoll et al. (1984).

Major-Element Data.-Sandstones were crushed to pieces $<4 \mathrm{~mm}$ using a jaw crusher and then powdered using a corundum ball mill. Loss on ignition (LOI) was determined by heating the dried samples up to $950^{\circ} \mathrm{C}$ for two hours. Sample powder was then mixed (1:10) with a 2:1 mixture of lithium tetraborate $\left(\mathrm{Li}_{2} \mathrm{~B}_{4} \mathrm{O}_{7}\right)$ and lithium metaborate $\left(\mathrm{LiBO}_{2}\right)$ to prepare fusion discs. Major-element data were determined on fusion discs by $\mathrm{X}$ ray fluorescence spectrometry with a Philips PW 2400 wavelength-dispersive spectrometer system using a Rh tube. Relative errors on major elements are usually less than $2 \%$. For statistical calculations, major-element oxides were recalculated to $100 \%$ with the LOI included. Total iron is expressed as $\mathrm{Fe}_{2} \mathrm{O}_{3}$.

Trace-Element Data.-The data were obtained using the same analytical equipment as for major elements but trace elements were measured on pressed powder pellets. Relative errors on trace elements are usually less than 5\%. Pressed powder pellets are much easier and faster to produce than fusion discs, and therefore we treat trace-element analysis as an independent method. This is because, if samples are already well discriminated by trace elements, there is no need to analyze major elements for discrimination purposes.

\section{Statistical Methods}

In order to analyze the data obtained by the four different methods with statistical rigor we follow the method suggested by Aitchison (1986). All data sets are compositional data, which means that they are restricted to values between 0 and 1 (or 100\%) and are subjected to the constant-sum constraint. This constraint means that all variables sum to a constant (e.g., $100 \%$ ) and, consequently, cannot vary independently from each other. This implies that compositional raw data cannot follow a multivariate normal distribution and therefore fail a major prerequisite of parametric statistical methods, such as standard discriminant analysis. The method of Aitchison (1986) is based fundamentally on the logratio transformation of the compositional data. This means, that a $d$-dimensional composition $x=\left(\mathrm{x}_{1}, \mathrm{x}_{2}\right.$, $\left.\ldots, x_{d}\right)$ is transformed to $y=\left(\ln \left(\mathrm{x}_{1} / x_{d}\right), \ln \left(x_{2} / x_{d}\right), \ldots, \ln \left(x_{d-1} / x_{d}\right)\right)$. The choice of the denominator (here: $x_{d}$ ) of the logratio transformation is not critical to the results (Aitchison 1986). This operation transforms the data from their constrained sample space, the simplex $S^{d}$, into the real space $R^{d-1}$, where parametric statistical methods can be applied to the transformed data (Aitchison 1986). For applying logratio transformations to the

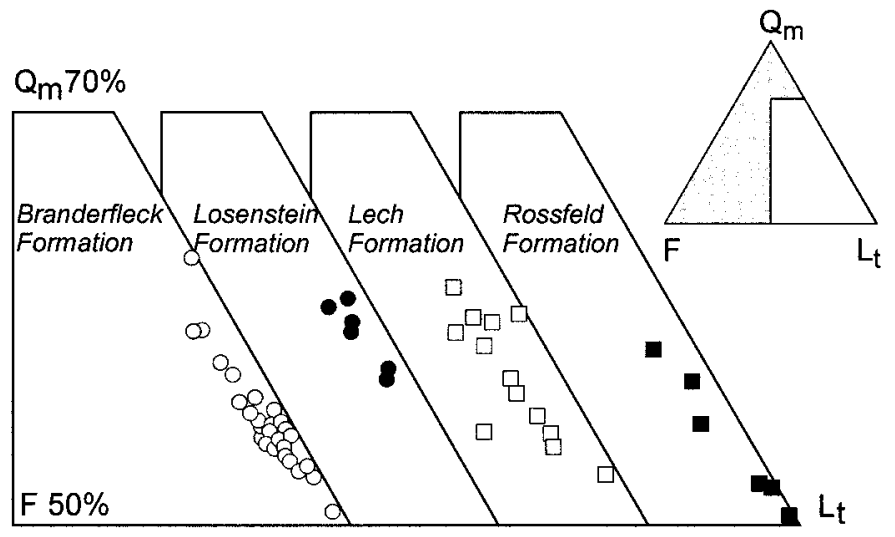

FIG. 4.-Sandstone light-mineral compositions illustrated in QmFLt diagrams. All samples $(n=52)$ are litharenites.

data sets, zero values must be replaced by small positive values. In the chemical data sets no zeros occur, but zero values are present in both mineralogical (light and heavy minerals) point-count data sets. We applied the method of replacement suggested by Martín-Fernández et al. (2000) assuming that zero values are not essential zeros. As a reasonable input value for zero replacement we choose $0.1 \%$, which corresponds to $20-33 \%$ of the lowest measurable value according to 200-300 point counts.

Biplot Analysis.-Biplots describe graphically the pattern of relative variation of a multivariate data set by projection onto a plane fixed by principal components. It is traditionally defined (Gabriel 1971) using the first two principal components, but there is no need to restrict the diagram to these two axes. For a detailed description of biplot techniques see Krzanowski (1988). Aitchison (1990, 1997) applied the biplot to compositional data using the centered logratio transformation, i.e., the denominator of the ratios is given by the geometric mean of each composition. This implies

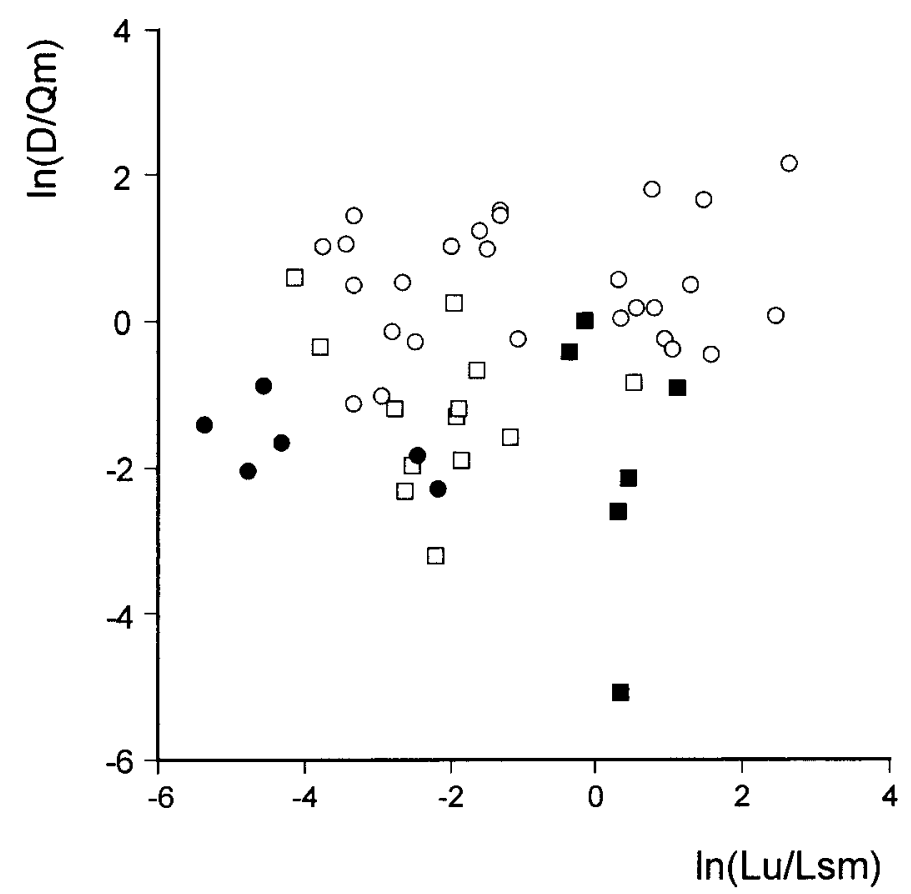

FIG. 5.-Logratios using specific lithoclasts and monocystalline quartz (Qm) grains allow a better seperation of formations than QmFLt diagrams. D, dolomite; $\mathrm{Lu}$, serpentinite; Lsm, metasedimentary lithoclasts. Symbols are the same as used in Figure 4. 


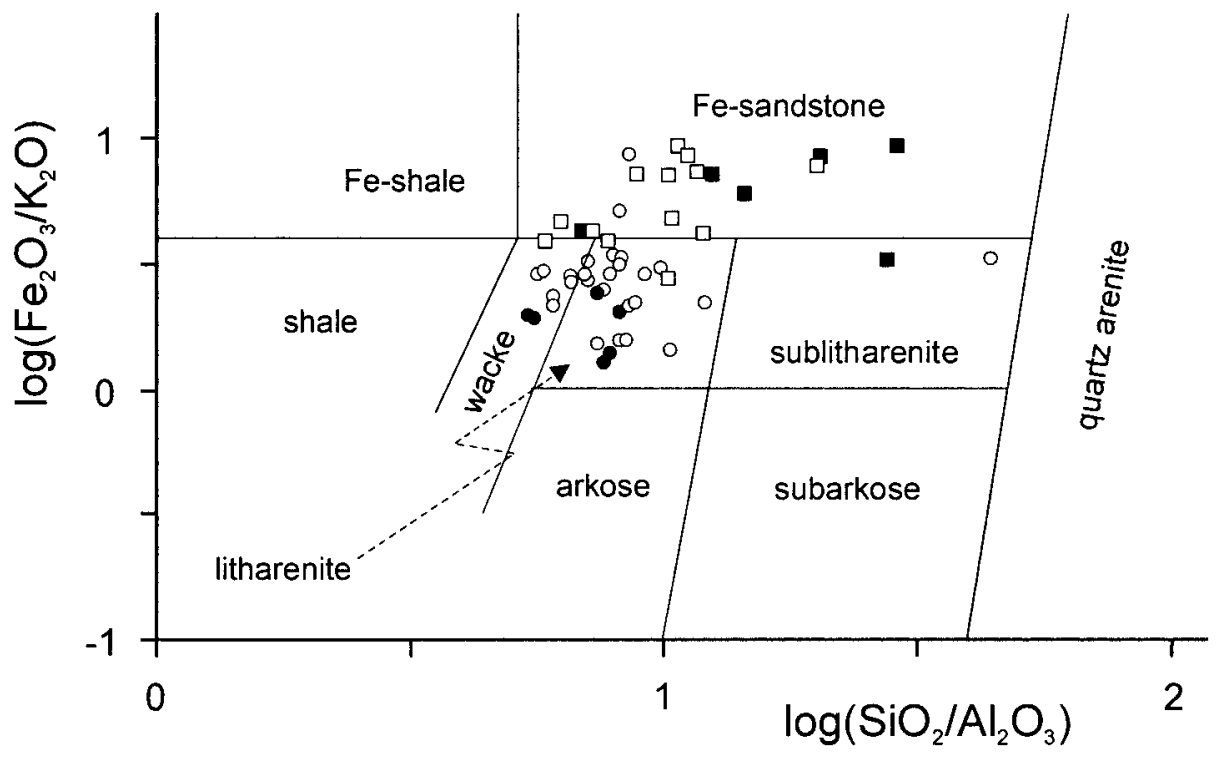

FIG. 6.-Chemical classification scheme of sandstones based on major elements (Herron 1988). Symbols are the same as used in Figure 4. that the origin of the biplot corresponds to the center (geometric mean) of the whole data set. The axes of the biplot correspond to principal components of the logcentered data (Fig. 7). A principal advantage of biplots is that they represent both the samples and the variables of compositional data. The former are termed cases, the latter vertices. For the interpretation of a biplot it is important to note that:

(1) The squared distance between a vertex and the origin corresponds to the variance of the logcentered variable. If the angle between the line from a vertex to the origin and an axis is small, the variable has a strong influence on the corresponding principal component. The larger the distance of the vertex to the origin and the smaller the angle, the stronger the influence. For example, the logcentered variable $\mathrm{Lu}$ (serpentinite clasts) of the light-mineral dataset (Fig. 7B) shows the highest relative variability of all light-mineral variables and strongly determines the first principal component. This is in contrast to most of the other variables, which have either close to no influence at all or more influence on the second component (Fig. 7B).

(2) The squared distance between two vertices corresponds to the variance of the logratios of these vertices (variables), which implies that nearly coincident vertices means that the variance of the logratios of these variables is near zero and, thus, the ratio is almost constant. A good example

TABLE 1.-Measured variables

\begin{tabular}{|c|c|c|c|c|}
\hline Method & $\begin{array}{c}\text { Heavy } \\
\text { Mineral } \\
\text { Analysis }\end{array}$ & $\begin{array}{l}\text { Light } \\
\text { Mineral } \\
\text { Analysis }\end{array}$ & $\begin{array}{l}\text { Major } \\
\text { Element } \\
\text { Analysis }\end{array}$ & $\begin{array}{c}\text { Trace } \\
\text { Element } \\
\text { Analysis }\end{array}$ \\
\hline No. of variables & 11 & 11 & 11 & 15 \\
\hline Variables & $\begin{array}{l}\text { chrome spinel (csp) } \\
\text { zircon (zr) } \\
\text { tourmaline (to) } \\
\text { rutile (rt) } \\
\text { garnet }(\mathrm{gt}) \\
\text { chloritoid (cd) } \\
\text { blue amphibole (gl) } \\
\text { epidote minerals (ep) } \\
\text { green amphibole (ac) } \\
\text { apatite (ap) } \\
\text { others* }\end{array}$ & $\begin{array}{l}\text { monocrystalline quartz }(\mathrm{Qm}) \\
\text { polycrystalline quartz }(\mathrm{Qp}) \\
\text { microcrystalline quartz, chert }(\mathrm{Qc}) \\
\text { feldspar }(\mathrm{F}) \\
\text { metasedimentary lithoclasts }(\mathrm{Lsm}) \\
\text { ultrabasic clasts (serpentinite, } \mathrm{Lu}) \\
\text { volcanic lithoclasts (Lv) } \\
\text { micritic calcite extraclasts }(\mathrm{Cm}) \\
\text { sparitic calcite extraclasts }(\mathrm{Cs}) \\
\text { dolmite extraclasts (D) } \\
\text { others** }\end{array}$ & $\begin{array}{l}\mathrm{SiO} 2 \\
\mathrm{TiO} 2 \\
\mathrm{Al} 2 \mathrm{O} 3 \\
\mathrm{Fe} 2 \mathrm{O} 3(\mathrm{t}) \\
\mathrm{MnO} \\
\mathrm{MgO} \\
\mathrm{CaO} \\
\mathrm{Na} 2 \mathrm{O} \\
\mathrm{K} 2 \mathrm{O} \\
\mathrm{P} 2 \mathrm{O} 5 \\
\mathrm{LOI}\end{array}$ & $\begin{array}{l}\mathrm{Ba} \\
\mathrm{Co} \\
\mathrm{Cr} \\
\mathrm{Cu} \\
\mathrm{Ga} \\
\mathrm{Nb} \\
\mathrm{Ni} \\
\mathrm{Pb} \\
\mathrm{Rb} \\
\mathrm{Sc} \\
\mathrm{Sr} \\
\mathrm{V} \\
\mathrm{Y} \\
\mathrm{Zn} \\
\mathrm{Zr}\end{array}$ \\
\hline
\end{tabular}

* Traces of brown amphibole, tremolite, pumpellyite, brookite/anatase, barite, and anhydrite.

** Traces of sedimentary intraclasts, bioclasts, mica, chlorite, glauconite, and heavy minerals. can be seen in both trace-element biplots (Fig. 7D) where the logcentered variables $\mathrm{Cr}$ and $\mathrm{Ni}$ lie close together, implying that the ratio $\mathrm{Cr} / \mathrm{Ni}$ is relatively constant.

(3) The distance between two samples (cases) is a measure of the similarity of the two samples and, thus, strong clustering of samples implies that these samples show strong similarities in composition.

It must be stressed that biplots serve as a descriptive tool for a first evaluation of the data. All statements based on biplots should be regarded as hints for further quantitative examinations but not as a final result. This is because only a portion of the total variability is explained by the twodimensional projection. The proportion of the variability explained can be taken as a measure of the strength of an individual biplot in interpreting the data. Obviously, if the proportion is exactly or near to $100 \%$, results obtained by graphical biplot interpretation are very robust.

Discriminant Analysis.-We performed the linear discriminant analysis using standard software routines (MINITAB, SPSS) applied to the additive logratio transformed data. For principles of multivariate discriminant function analysis the reader is referred to, e.g., Krzanowski (1988). The choice of the denominator of the logratio transformation is not critical to the results (see above). Choosing a denominator that is assumed to be valuable for discrimination may be helpful if a later reduction of the variables necessary for discrimination is intended. For linear discriminant analysis we have to assume that the transformed data of individual classes are samples of multivariate normal distributions with the same covariance matrix.

In the general procedure, the best linear discriminant functions between the classes (e.g., the four formations) were calculated for each of the four methods using all of the available samples. Then each individual sample was classified according to the discriminant functions and a rate of wellclassified samples was calculated for each class (formation) and each method. In a second step, the procedure was repeated for each individual sample with linear discriminant functions calculated using all of the samples minus this individual one. The latter technique is known as cross-validation and satisfies the condition that the data to be classified should not be used for the formulation of the classification rules. To provide additional information on differences in composition between the four classes (formations), we use the Mahalanobis distance. Given that the Mahalanobis distance includes all of the variability of the sample classes, it can be used as a measure of the separation of classes (Krzanowski 1988). Because the method that discriminates best among all of the four formations is not necessarily the one that discriminates best between any two formations, we also 


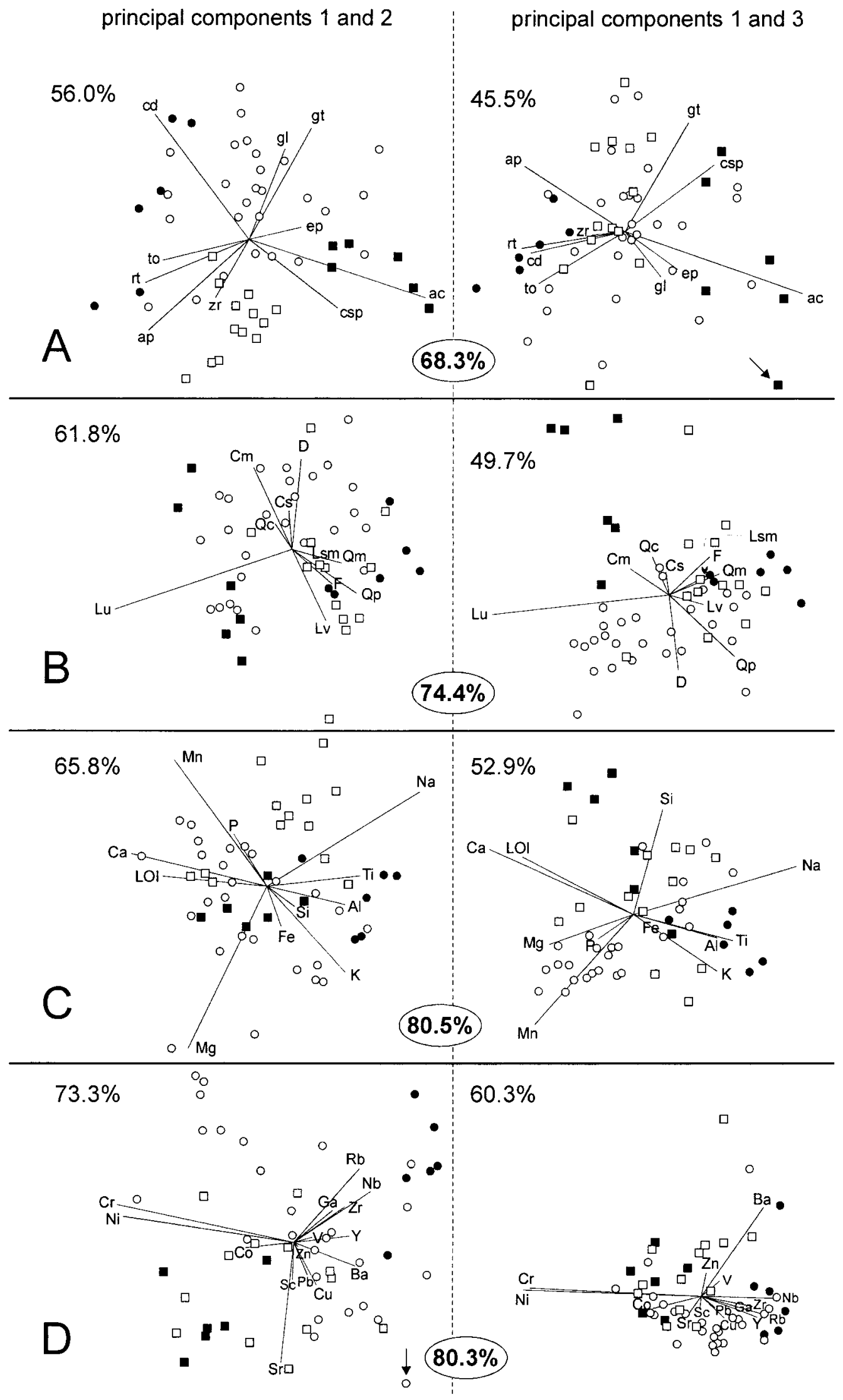


have applied hierarchic discriminant analysis. This means that we separate first one formation from all the others, then a second one from the rest, and finally the two remaining formations from each other.

All variables of each analytical method (see Table 1) are used for the discriminant function analysis except for others (light-mineral and heavymineral data sets), LOI (major-element data set), and Cs (light-mineral data set). The former comprise the sum of mostly rare and poorly constrained variables. $\mathrm{LOI}$ is strongly related to $\mathrm{CaO}$ (see also Figure 7C: coincidence of $\mathrm{CaO}$ and $\mathrm{LOI}$ ) for mineralogical reasons because high carbonate contents (calcite, dolomite) imply both high $\mathrm{CaO}$ and high $\mathrm{CO}_{2}$ (resulting in high LOI) contents. The latter (Cs, sparitic calcite) was not used because it may be biased by diagenetic processes: differentiation between sparitic calcite grains and calcite cements is sometimes ambiguous in diagenetically altered sandstones.

\section{RESULTS}

\section{Descriptive Statistics: Biplot Analysis}

Biplots of the data obtained by the four methods are shown in Figure 7. For each method we choose two biplots (defined by the first and second and by the first and third principal components). Together these three components explain between $68 \%$ and $81 \%$ of the total variability.

The heavy mineral data show several mineral phases with comparably high relative variability spread in all directions of the biplot (Fig. 7A). A similar pattern is observed for the major-element data (Fig. 7C). Here, the small distance between the $\mathrm{CaO}$ and $\mathrm{LOI}$ vertices in both major-element analysis biplots indicate that the ratio $\mathrm{CaO} / \mathrm{LOI}$ is relatively constant, which results from the high carbonate content (CE clasts) of the sandstones (von Eynatten and Gaupp 1999). The variability pattern of the light-mineral data (Fig. 7B) is quite different, because one variable $(\mathrm{Lu})$ shows a much higher relative variability than all the other variables. This variable also has a strong influence on the first principal component, followed by Qp, whereas the other variables have either a small relative variability in general (e.g., Qs, Lsm, Cs, Qm, F) or a stronger influence on the second principal component (e.g., Cm, D, Lv). A similar pattern is observed for the trace-element data (Fig. 7D), where two variables (Cr, Ni) have a much higher relative variability than do the others and these two variables also influence strongly the first principal component. The distance $\mathrm{Cr}-\mathrm{Ni}$ is very small in both trace-element biplots, indicating that their ratio is relatively constant.

The similarity of light-mineral and trace-element biplot patterns is related to the nearly exclusive occurrence of $\mathrm{Cr}$ and $\mathrm{Ni}$ in serpentinite lithoclasts $(\mathrm{Lu})$ : a high relative variability of $\mathrm{Lu}$ in the light-mineral data set forces a high relative variability of $\mathrm{Cr}$ and $\mathrm{Ni}$ in the trace-element data set. This cannot be seen in the major-element data because the specific major-element component of serpentinite is $\mathrm{Mg}$, which is obscured because of its concurrent occurrence in volcanic (Lv) and dolomite lithoclasts (D). It also is not seen in the heavy-mineral analysis biplot, although nearly all of the trace-element $\mathrm{Cr}$ should be derived from the heavy mineral chrome spinel (csp). The reason may be that the trace-element data were derived from the whole rock, whereas the heavy-mineral analysis data consider only a specific part of the whole-rock mineralogy, i.e., heavy minerals in sand size fraction (here: $63-125 \mu \mathrm{m}$ ). Thus, the greater part of $\mathrm{Cr}$ is probably derived from microcrystalline chrome spinel within serpentinite lithoclasts $(\mathrm{Lu})$, which cannot be recognized by heavy-mineral analysis.

With regard to discrimination, the biplots demonstrate that there are clusters of samples belonging to a given formation, e.g., Lech Formation sam- ples in the heavy-mineral biplot (Fig. 7A, principal components 1 and 2) or Branderfleck Formation samples in the major-element biplot (Fig. 7C, principal components 1 and 3). At first glance, separation of formations seems to work best in the heavy-mineral biplot (Fig. 7A, principal components 1 and 2), but only $56 \%$ of the total variability is explained within this diagram. The separation is not convincing on the heavy mineral biplot of principal components 1 and 3 . In general, the data show distinct differences in compositions with respect to the four formations, but a discrimination of all of them seems to be questionable. Such a full discrimination can be tested by applying discriminant analysis.

\section{Statistical Inference: Discriminant Analysis}

The results of linear discriminant analysis are expressed as percentages of well classified samples both without (DA) and with cross-validation (DAX). Additional information comes from the squared Mahalanobis distance $\left(\mathrm{MD}^{2}\right)$, a measure of separation of different groups (Table 2). If $\mathrm{MD}^{2}$ $>9$ and DAX $>80 \%$, the specific discrimination is considered to satisfy the conditions of sufficient discrimination. These limits were chosen because (1) values of $\mathrm{MD}^{2}>9$ correspond to a $>3$ sigma distance between the means of two groups in the univariate case and is thus considered to indicate a reasonable separation of groups, and (2) values of well classified samples which exceed $80 \%$ are generally considered to be acceptable (e.g., Herron 1988) and correspond to values obtained by classical methods of provenance determination (Molinaroli et al. 1991).

None of the analytical methods allow a perfect discrimination of all of the four formations. Using standard linear discriminant analysis (DA) all methods fulfill the $80 \%$ criterion, except for heavy-mineral analysis, which fails this criterion for Branderfleck Formation samples (78\%). Using cross validation (DAX), both of the mineralogical methods (light-mineral and heavy-mineral analysis) fail the $80 \%$ criterion for two out of four formations, whereas both of the chemical methods (major-element and traceelement analysis) fail this criterion for one formation. DAX values are lowest using light-mineral data (50\% and 39\%), and this method also displays some very low $\mathrm{MD}^{2}$ values. On the basis of the latter, light-mineral data demonstrate a very poor separation between the Lech and Losenstein formations $\left(\mathrm{MD}^{2}=2\right)$ as well as between the Lech and Branderfleck formations $\left(\mathrm{MD}^{2}=5\right.$, Table 2). The other three analytical methods all display sufficiently high $\mathrm{MD}^{2}$ values to separate between the four formations. Summarizing the simultaneous discrimination of all formations, we can state that (1) the discriminative power of chemical methods is better than that of mineralogical methods, and (2) heavy-mineral analysis discriminates better than light-mineral analysis.

Because hierarchic discriminant analysis may lead to a better discrimination of classes, this procedure is also applied. To avoid the confusion of demonstrating all possible steps, we only present all possible first (discrimination of one formation from the other formations) and last steps (discrimination between two formations). The parameters of the resulting ten discriminant analyses for each of the methods are given in Table 2 and are illustrated in Figure 8. DA values mostly exceed $90 \%$ regardless of the method. Using the more critical parameters DAX and $\mathrm{MD}^{2}$ the worst results are again given by light-mineral analysis, with 6 out of 10 analyses not satisfying the criteria of sufficient discrimination. Again both chemical methods are quite similar ( 3 out of 10 analyses fail), but using hierarchic discriminant analysis heavy-mineral analysis gives the best discrimination (1 out of 10 analyses fails).

$\leftarrow$

FIG. 7.-Biplots of compositions obtained by the four methods. A) heavy-mineral data, B) light-mineral data, C) major-element data, D) trace-element data. Axes are first and second (left side) and first and third (right side) principal components; first principal component as horizontal axis in both cases. Percentages indicate proportions of total variability explained by an individual biplot. Bold percentages indicate proportions of total variability explained by both of the biplots. Symbols are the same as used in Table 1 (variables) and Figure 4 (formations). 
TABLE 2.-Summary of discriminant analysis

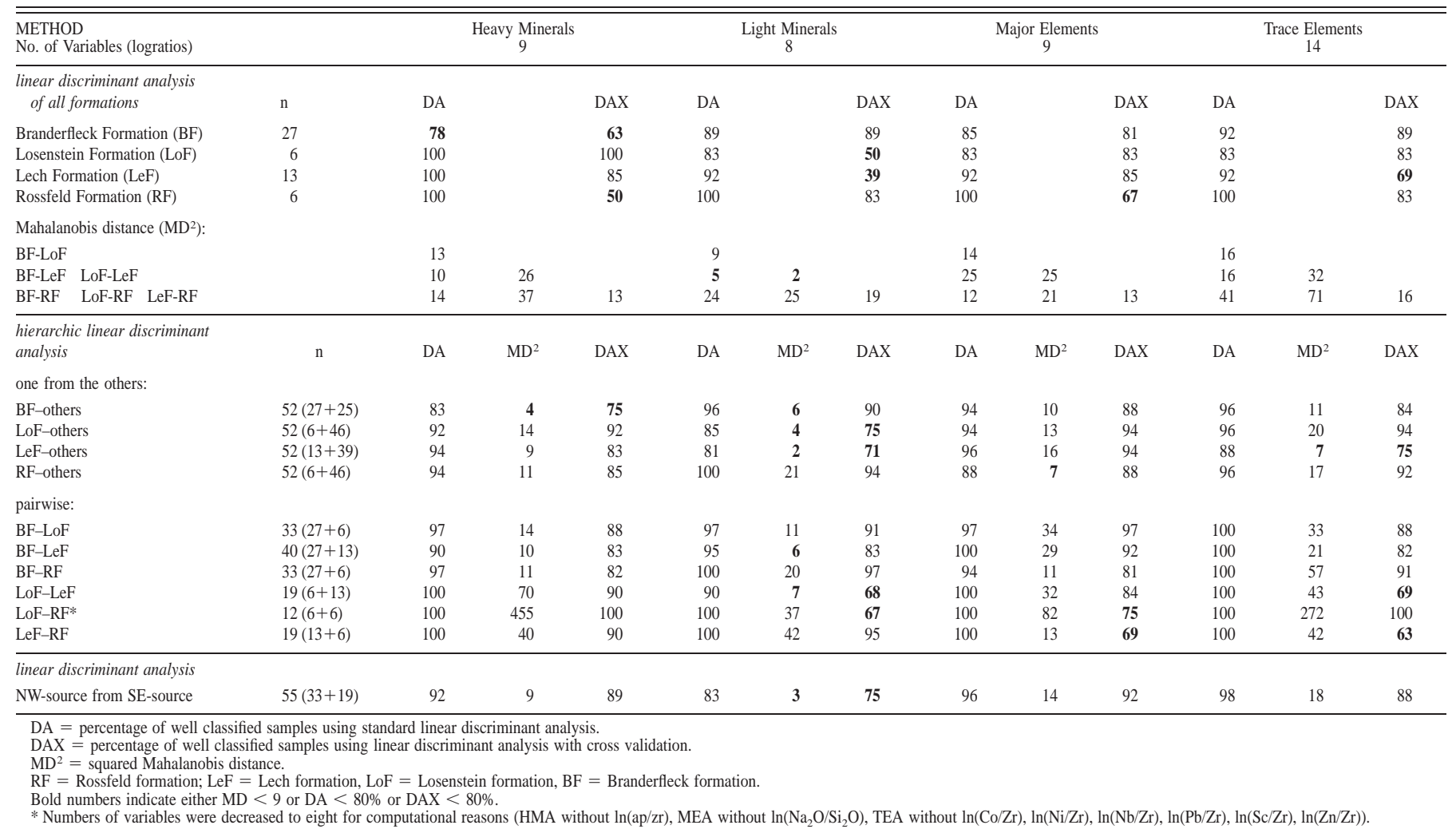

The last calculations consider the discrimination between the two different source areas, which, in fact, means the discrimination of Branderfleck and Losenstein formations from Lech and Rossfeld formations (Table 2, Fig. 8). Using light-mineral data both parameters $\left(\mathrm{MD}^{2}=3, \mathrm{DAX}=75 \%\right)$ fail the criteria for sufficient discrimination, whereas using heavy-mineral, major-element, and trace-element data discrimination between source areas passes these criteria. The weak separation $\left(\mathrm{MD}^{2}=3\right)$ depends strongly on the very poor separation between Losenstein and Lech formations, because this separation is crucial for the separation of the two source areas (von Eynatten and Gaupp 1999).

In summary, the discrimination of formations and source areas on the basis of heavy-mineral, major-element, and trace-element analysis mostly passes the criteria of sufficient discrimination as defined above, whereas discrimination based on light-mineral analysis mostly fails these criteria. The former three methods display no systematic differences with respect to both discrimination parameters. These results suggest that trace-element analysis exhibits the best relationship of low analytical expenditure and high discriminative power with respect to the analyzed case study.

\section{DISCUSSION}

The most frequently used method to determine sandstone composition is thin-section petrography (light-mineral analysis). This is partly because several decades ago, when sedimentary petrology became a growing subdiscipline of geology (e.g., Pettijohn 1957), thin-section preparation and microscopy were accessible techniques for most geologists. However, lightmineral analysis still has strong advantages compared to chemical methods, because (1) analyzing the complete framework of a sandstone allows for the distinction between detrital and diagenetic phases, and (2) light-mineral analysis allows for the differentiation of textures of individual grains even if they are chemically and/or mineralogically similar. In fact, light-mineral analysis is capable of contributing to several specific problems in sedi- mentary petrology and provenance analysis that cannot be solved by other methods, e.g., petrologic studies of sandstone diagenesis (e.g., Gaupp 1996) or the use of very detailed classifications of unaltered lithic grains or quartz fabrics to evaluate unroofing histories in the source areas (e.g., Dorsey 1988).

On the other hand, light-mineral analysis also has several disadvantages. Concerning analytical expenditure, point-counting methods are quite timeconsuming compared to modern XRF techniques, which allow rapid acquisition of large numbers of precise chemical analyses (Rollinson 1993). There are relatively high methodical errors (counting statistics) in the quantification of individual variables (van der Plas and Tobi 1965) superimposed on possible operator bias due, in part, to subjective criteria for the separation of individual grain types (Dickinson 1970; Wolf 1971; Ingersoll et al. 1985; Suttner and Basu 1985). Despite these errors in quantification, light-mineral analysis and the models of classification or provenance determination relying on it (e.g., QFL and QmFLt diagrams of Dickinson 1985) often are used uncritically (Ingersoll 1990).

A further pitfall of light-mineral analysis is the physical or chemical decomposition of relatively unstable grains in the course of diagenesis (e.g., Milliken 1988). Those grains carrying most information on provenance (feldspars and lithoclasts) are most prone to be degraded. This process generates fine-grained material mostly composed of clay minerals (pseudomatrix), which can no longer be identified by optical means. For a review of problems involved with such "pseudomatrix" we refer to Cox and Lowe (1996) and we use the term in their sense. Modifying the method by a combined microscopic-EDX approach (Bangs Rooney and Basu 1994) allows the determination of certain precursor minerals (or mineral aggregates) of the pseudomatrix but enhances the analytical expenditure and cannot be considered a purely petrographic method.

Some disadvantages involved with light-mineral analysis commonly are thought to be circumvented by chemical analyses, especially when studying 


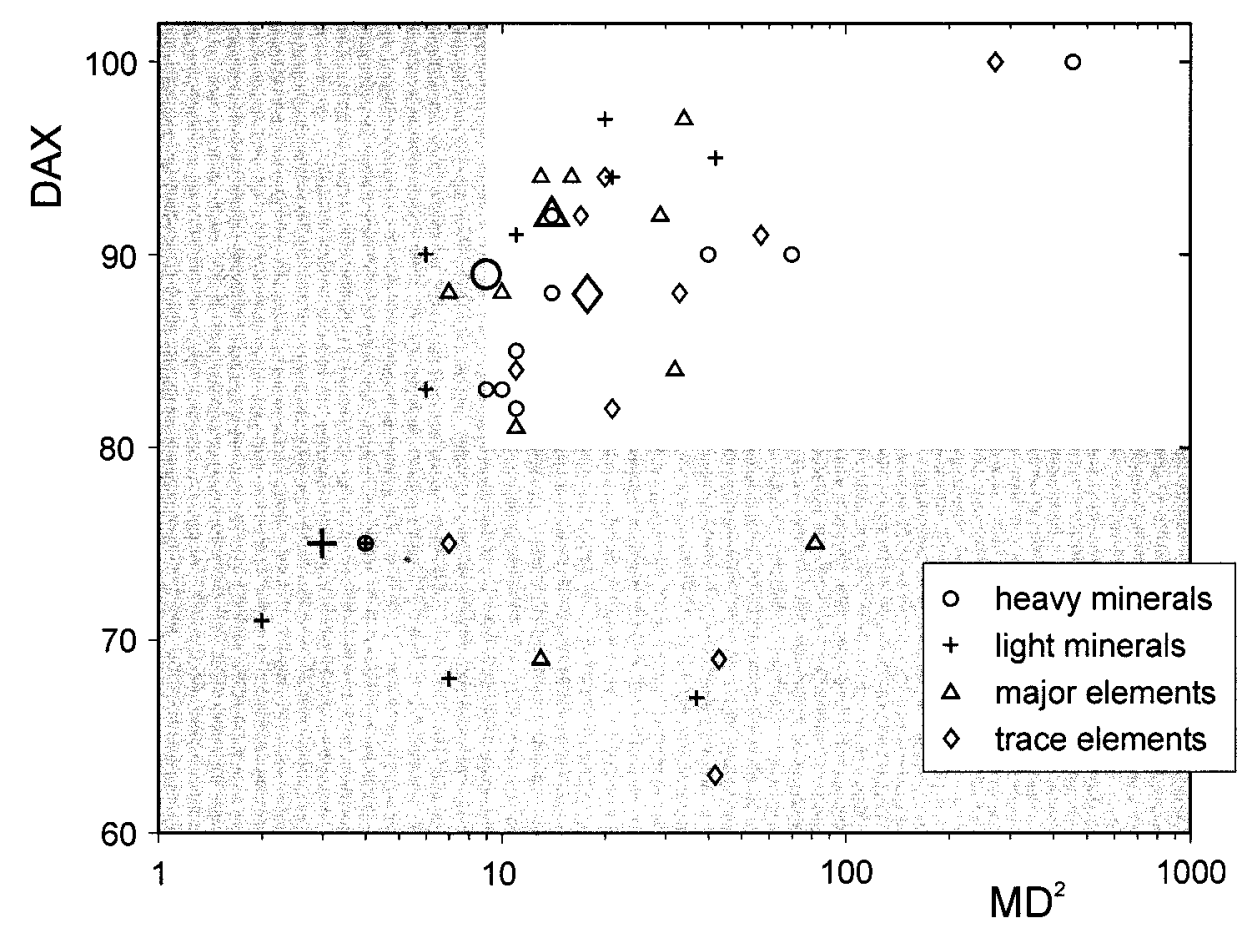

FIG. 8.-Squared Mahalanobis distance (MD²) vs. percentage of well classified samples with cross validation (DAX) for the ten hierarchic discriminations (see Table 2) of each method. Gray area indicates insufficient discriminations with $\mathrm{MD}^{2}<9$ and/or DAX $<80 \%$. Large symbols represent data from the discrimination between the two source areas (NW source vs. SE source). muddy sandstones or altered arkoses and litharenites with high amounts of pseudomatrix ("graywackes," e.g., Bhatia and Crook 1986; McLennan et al. 1993). But quantitative approaches comparing the results of both chemical and mineralogical methods applied to the same suite of samples are very rare.

In a multi-method study of modern sediments of the Calabrian arc, Ibbeken and Schleyer (1991) statistically tested the discriminative power of different methods and grain sizes with respect to the separation of source areas. Considering the sand size fraction, heavy-mineral analysis discriminated best, major-element analysis intermediate, and light-mineral analysis worst. Molinaroli et al. (1991) applied discriminant analysis to mineralogical and chemical methods of provenance determination using case studies from the literature. They find similar results for the individual data sets ranging from $74 \%$ to $85 \%$ (on average) of well classified samples, but this is not truly a comparative study in that different methods were applied to the same samples. Molinaroli et al. (1991) observed low percentages of well classified samples (55-73\%) for the magmatic-arc subprovinces of the light-mineral QFL and QmFLt provenance diagrams of Dickinson (1985). This observation is in agreement with the statement of Butler and Woronow (1986) that the subdivision of the magmatic-arc province may well be an artifact of the constant-sum constraint of compositional data.

Our study suggests that the discriminative power of light-mineral analysis is significantly lower than the other three applied methods, particularly when evaluating samples of a single sandstone class (e.g., litharenites). Taking into account the analytical expenditure for data acquisition, traceelement analysis appears to be the most efficient method for the discrimination of the analyzed sandstones. Although the results are based on only a single case study, we propose a more general applicability of this conclusion for the following reasons:

(1) The analyzed sandstones are immature litharenites with a high proportion of lithoclasts. Although affected by a considerable tectonic and thermal overprint, lithoclasts still show a wide range of distinguishable types (e.g., serpentinite, quartz-chlorite-mica aggregates, volcanics, chert, dolomite, micritic calcite). This high diversity of lithoclasts is due to a complex hinterland (von Eynatten and Gaupp 1999). Therefore, these sandstones should have a high potential for a good discrimination by light- mineral analysis compared to more mature sandstones like sublitharenites or quartzarenites. Nevertheless light-mineral analysis mostly fails statistical criteria for sufficient discrimination.

(2) Our results are supported by a previous study of modern sediments of the Calabrian arc by Ibekken and Schleyer (1991) that was based on a much larger number of samples. The clasts of these immature sediments are not modified by diagenetic processes, implying that all the information obtainable by light-mineral analysis is available for discrimination. Nevertheless, light-mineral analysis exhibits again the weakest discriminative power of all applied methods, including heavy-mineral analysis and majorelement analysis.

(3) The larger the number of variables and the better these variables are defined, the better a multivariate discriminant analysis can be. Light-mineral analysis of diagenetically altered litharenites is quite limited in the number of precisely distinguishable variables and generally displays relatively high errors on individual variables. In contrast to counting methods, chemical analysis (e.g., XRF analysis of major and trace elements) usually displays much lower errors on individual variables, and in case of traceelement analysis the number of variables may be markedly larger.

The latter point is considered to be valid for sandstones affected by a noticeable diagenetic overprint, but in case of unconsolidated sands or sandstones with low diagenetic imprint the number of variables obtainable by light-mineral analysis may be markedly larger than the number of variables obtainable by trace-element analysis. The results from this study cannot be generally extended to all kinds of sands and sandstones, but the type of sandstones considered here are very common (e.g., foreland basins) and form about $50 \%$ of all sands and sandstones (litharenites and graywackes; Pettijohn et al. 1987).

As mentioned above, chemical whole-rock analysis does not provide information on texture and authigenesis of sandstones. For example, quartzarenites composed exclusively of varying contents of quartz and pure chert grains will probably not be discriminated succesfully by chemical methods. In some cases, diagenetic mineral phases may be the only cause for contrasting chemical compositions and, hence, their occurrence may cause discrimination of sandstones based on whole-rock geochemistry without any 
relation to sandstone provenance. However, these effects can be easily detected by qualitative petrography without using point-count techniques.

The method with the greatest discriminative power is thought to discriminate best between groups of samples with different compositions. Because sandstone composition is controlled by geologic conditions such as source rocks, climate, and diagenesis, changes in composition reflect changes in one or more of these conditions. Consequently, a significant change in geologic conditions should be recorded in the sandstones, and the most prominent way to evaluate such changes is to look for statistically significant changes in sandstone composition. The higher the discriminative power of the chosen method to analyze sandstone composition, the higher is the chance to dectect such statistically significant changes. Obviously, the method with the higher discriminative power does not necessarily contribute most to the interpretation of geologic conditions like, e.g., provenance. But (1) evaluating the potential for significant differences in sandstone composition should be among the first steps when trying to understand the geologic history of a suite of sandstones, and (2) use of statistical tools such as biplots of logratio-transformed compositional data gives useful hints to the further interpretation of the data (e.g., the high variability of $\mathrm{Cr}$ and $\mathrm{Ni}$ and their strong influence on the first principal component, Fig. 7D).

The provenance model for the sandstones of this case study is based mainly on heavy-mineral analysis and single grain geochemistry of several detrital mineral phases (von Eynatten and Gaupp 1999). It would definitely not have been possible to establish the model solely on the basis of wholerock chemical analyses. This is in agreement with recent developments favoring multi-method approaches to sandstone provenance (e.g., Haughton et al. 1991; Morton and Hallsworth 1999; von Eynatten et al. 1999). Once a provenance model is established and appropriate discriminant functions between contrasting sources are calculated, chemical analysis of an unknown sample should allow us to assign this sample to its source. From our results, a high probability of correct classification combined with lowest analytical expenditure is achieved by using XRF trace-element analysis on pressed powder pellets.

\section{CONCLUSIONS}

Four different analytical methods were applied to a suite of diagenetically altered Cretaceous litharenites to evaluate the discriminative power of each method with respect to different formations and source areas. The results imply that light-mineral analysis has the lowest discriminative power of the applied methods. Trace-element analysis on pressed powder pellets provides a high discriminative power combined with the lowest analytical expenditure.

On the basis of comparison with other studies, these results are interpreted to have a more general meaning with respect to the discrimination of sandstones based on composition. We are aware, however, that this is not proven to be valid for all kinds of sandstones. In the case of less mature and diagenetically altered sandstones (e.g., litharenites and graywackes) chemical analysis appears to be more precise and efficient with respect to discrimination purposes.

Sandstone composition is strongly related to the provenance of sediment, which is largely controlled by source rocks, climate, and relief (e.g., Johnsson 1993). Because of a complex interaction of these factors, data based on a single analytical method mostly do not allow us to develop a precise provenance model. But if a provenance model already exists and discriminant functions are calculated for the sample suite the model relies on, traceelement analysis provides a fast and promising tool to assign an unknown sample to its appropriate source. If no such model exists, chemical analysis provides a quick tool for a first estimate of the discriminative potential of a sample suite.

Finally, we wish to emphasize that applying rigorous statistical methods to compositional data may enhance the strength of conclusions that are based on data of this kind. The logratio approach of Aitchison (1986) provides a powerful tool for analyzing compositional data, and we therefore encourage its use whenever sandstone compositions are analyzed statistically.

\section{ACKNOWLEDGMENTS}

This study was performed during a sabbatical stay of $\mathrm{HvE}$ at Universitat Politecnica de Catalunya in Barcelona and Universitat de Girona. HvE acknowledges funding by the Deutsche Forschungsgemeinschaft (grant EY 23/2). We appreciate discussions and presubmission reviews by Reinhard Gaupp and Thomas Voigt. The manuscript benefited from thorough and stimulating comments by JSR reviewers John Aitchison, José Arribas, Mark J. Johnsson, Ken Ridgway, and Alex Woronow. Careful editorial handling by David A. Budd and Mark J. Johnsson is greatfully acknowledged. The chemical data described in this paper have been archived, and are available in digital form, at the World Data Center-A for Marine Geology and Geophysics, NOAA/NGDC, 325 Broadway, Boulder, CO 80303; (phone: 303-4976339; fax: 303-497-6513; E-mail: wdcamgg@ngdc.noaa.gov; URL: http:// www.ngdc.noaa.gov/mgg/sepm/archive/index.html).

\section{REFERENCES}

Aitchison, J., 1986, The Statistical Analysis of Compositional Data: London, Chapman \& Hall, $416 \mathrm{p}$.

Aitchison, J., 1990, Relative variation diagrams for describing patterns of compositional variability: Mathematical Geology, v. 22, p. 487-511.

Aitchison, J., 1997, The one-hour course in compositional data analysis, or compositional data analysis is easy, in Pawlowsky-Glahn, V., Proceedings of IAMG'97, The Third Annual Conference of the International Association for Mathematical Geology, Barcelona, v. 1, p. $3-35$.

Bangs Rooney, C., AND Basu, A., 1994, Provenance analysis of muddy sandstones: Journal of Sedimentary Research, v. A64, p. 2-7.

Barceló-Vidal, C., Pawlowsky-Glahn, V., and Grunsky, E.C., 1997, A critical approach to the Jensen diagram for the classification of a volcanic sequence, in Pawlowsky-Glahn, V., Proceedings of IAMG'97, The Third Annual Conference of the International Association for Mathematical Geology, Barcelona, v. 1, p. 117-122.

Bhatia, M.R., and Crook, K.A.W., 1986, Trace element characteristics of greywackes and tectonic discrimination of sedimentary basins: Contributions to Mineralogy and Petrology, v. 92 , p. 181-193.

Butler, J.C., AND Woronow, A., 1986, Extracting genetic information from coarse clastic modes: Computers \& Geosciences, v. 12, p. 643-652.

Cardenas, A.A., Girty, G.H., Hanson, A.D., Lahren, M.M., Knaack, C., and Johnson, D., 1996, Assessing differences in composition between low metamorphic grade mudstones and high-grade schists using logratio techniques: Journal of Geology, v. 104, p. 279-293.

Cox, R., AND Lowe, D.R., 1996, Quantification of the effects of secondary matrix on the analysis of sandstone composition, and a petrographic-chemical technique for retrieving original framework grain modes of altered sandstones: Journal of Sedimentary Research, v. 66 , p. $548-558$.

Decker J., ANd Helmold, K.P., 1985, The effect of grain size on detrital modes: A test of the Gazzi-Dickinson point-counting method-Discussion: Journal of Sedimentary Research, v. 55 , p. 618-620.

Dickinson, W.R., 1970, Interpreting detrital modes of graywacke and arkose: Journal of Sedimentary Petrology, v. 40, p. 695-707.

Dickinson, W.R., 1985, Interpreting provenance relations from detrital modes of sandstones, in Zuffa, G.G., Provenance of Arenites: Dordrecht, The Netherlands, Reidel, p. 333-361.

Dickinson, W.R., AND SucZeK, C.A., 1979, Plate tectonics and sandstone compositions: American Association of Petroleum Geologists, Bulletin, v. 63, p. 2164-2182.

Dorsey, R.J., 1988, Provenance evolution and unroofing history of a modern arc-continent collision: evidence from petrography of Plio-Pleistocene sandstones, eastern Taiwan: Journal of Sedimentary Petrology, v. 58, p. 208-218.

Faupl, P., And WagreIch, M., 1992, Cretaceous flysch and pelagic sequences of the Eastern Alps: correlations, heavy minerals, and paleogeographic implications: Cretaceous Research, v. 13 , p. $387-403$.

Froitzheim, N., Schmid, S.M., AND Frey, M., 1996, Mesozoic paleogeography and the timing of eclogite-facies metamorphism in the Alps: a working hypothesis: Eclogae Geologicae Helvetiae, v. 89, p. 81-110.

FüchtBauer, H., 1964, Sedimentpetrographische Untersuchungen in der älteren Molasse nördlich der Alpen: Eclogae Geologicae Helvetiae, v. 57, p. 157-298.

GABRIEL, K.R., 1971, The biplot-graphic display of matrices with applications to principal component analysis: Biometrika, v. 58, p. 453-467.

GaupP, R., 1982, Sedimentationsgeschichte und Paläotektonik der kalkalpinen Mittelkreide (Allgäu, Tirol, Vorarlberg): Zitteliana, v. 8, p. 33-72.

GAuPP, R., 1996, Diagenesis types and their application to diagenesis mapping: Zentralblatt für Geologie und Paläontologie, Teil I, v. 1994, p. 1183-1199.

Gaupp, R., and Batten, D.J., 1985, Maturation of organic matter in Cretaceous strata of the Northern Calcareous Alps: Neues Jahrbuch für Geologie und Paläontologie, Monatshefte, v. 1985 , p. $157-175$.

Haughton, P.D.W., Todd, S.P., and Morton, A.C., 1991, Sedimentary provenance studies, in 
Morton, A.C., Todd, S.P., and Haughton, P.D.W., Developments in Sedimentary Provenance Studies: Geological Society of London, Special Publication 57, p. 1-11.

Heins, W.A., 1993, Source rock texture versus climate and topography as controls on the composition of modern, plutoniclastic sand, in Johnsson, M.J., and Basu, A., Processes Controlling the Composition of Clastic Sediments: Geological Society of America, Special Paper 284, p. 135-146.

HerRon, M.M., 1988, Geochemical classification of terrigenous sands and shales from core or log data: Journal of Sedimentary Petrology, v. 58, p. 820-829.

IbBeken, H., and Schleyer, R., 1991, Source and Sediment: Berlin, Springer, 286 p.

InGERSoLl, R.V., 1990, Actualistic sandstone petrofacies: Discriminating modern and ancient source rocks: Geology, v. 18, p. 733-736.

Ingersoll, R.V., Bullard, T.F., Ford, R.L., Grimm, J.P., Pickle, J.D., and Sares, S.W., 1984 The effect of grain size on detrital modes: a test of the Gazzi-Dickinson point-counting method: Journal of Sedimentary Petrology, v. 54, p. 103-116.

Ingersoll, R.V., Bullard, T.F., Ford, R.L., and Pickle, J.D., 1985, The effect of grain size on detrital modes: a test of the Gazzi-Dickinson point-counting method-Reply: Journal of Sedimentary Petrology, v. 55, p. 617-618.

Johnsson, M.J., 1993, The system controlling the composition of clastic sediments, in Johnsson, M.J., and Basu, A., Processes Controlling the Composition of Clastic Sediments: Geological Society of America, Special Paper 284, p. 1-19.

Krzanowski, W.J., 1988, Principles of Multivariate Analysis; A User's Perspective: Oxford, U.K., Clarendon Press, 563 p.

Mange, M.A., AND Maurer, H.F.W., 1991, Schwerminerale in Farbe: Stuttgart, Enke, 148 p. Martín-Fernández, J.A., Barceló-Vidal, C., and Pawlowsky-Glahn, V., 2000, Zero replacement in compositional data sets, in Kiers, H.A.L., Rasson, J.-P., Groenen, P.J.F., and Schader, M., Advances in Data Science and Classification, Proceedings of the 7th Conference of the International Federation of Classification, IFCS 2000, Namur: Berlin, Springer, p. 155160 .

McBride, E.F., 1963, A classification of common sandstones: Journal of Sedimentary Petrology, v. 33, p. 664-669.

McLennan, S.M., Hemming, S., McDaniel, D.K., and Hanson, G.N., 1993, Geochemical approaches to sedimentation, provenance, and tectonics, in Johnsson, M.J., and Basu, A., Processes Controlling the Composition of Clastic Sediments: Geological Society of America, Special Paper 284, p. 21-40.

MilLiken, K.L., 1988, Loss of provenance information through subsurface diagenesis in PlioPleistocene sandstones, northern Gulf of Mexico: Journal of Sedimentary Petrology, v. 58 , p. $992-1002$.

Molinaroli, E., Blom, M., and Basu, A., 1991, Methods of provenance determination tested with discriminant function analysis: Journal of Sedimentary Petrology, v. 61, p. 900-908.

Morton, A.C., 1985, Heavy minerals in provenance studies, in Zuffa, G.G., Provenance of Arenites: Dordrecht, The Netherlands, Reidel, p. 249-277.

Morton, A.C., and Hallsworth, C., 1994, Identifying provenance-specific features of detrital heavy mineral assemblages in sandstones: Sedimentary Geology, v. 90, p. 241-256.

Morton, A.C., and Hallsworth, C.R., 1999, Processes controlling the composition of heavy mineral assemblages in sandstones: Sedimentary Geology, v. 124, p. 3-29.
ORI, G.G., AND FRIEND, P.F., 1984, Sedimentary basins formed and carried piggyback on active thrust sheets: Geology, v. 12, p. 475-478

Petтijohn, F.J., 1957, Sedimentary Rocks: 2nd edition, New York, Harper \& Brothers, 718 p. Pettijohn, F.J., Potter, P.E., and Siever, R., 1987, Sand and Sandstone, 2nd edition: New York, Springer, $553 \mathrm{p}$.

PotTer, P.E., 1978, Petrology and chemistry of modern big river sands: Journal of Geology, v. 86, p. $423-449$.

Rollinson, H., 1992, Another look at the constant sum problem in geochemistry: Mineralogical Magazine, v. 56, p. 469-475.

Rollinson, H., 1993, Using Geochemical Data: Essex, Longman, 352 p.

Suttner, L.J., AND Basu, A., 1985, The effect of grain size on detrital modes: a test of the Gazzi-Dickinson point-counting method-Discussion: Journal of Sedimentary Petrology, v. 55 , p. 616-617.

SutTner, L.J., Basu, A., AND MACK, G.H., 1981, Climate and the origin of quartz arenites: Journal of Sedimentary Petrology, v. 51, p. 1235-1246.

van de Kamp, P.C., AND LeaKe, B.E., 1995, Petrology and geochemistry of siliciclastic rocks of mixed feldspathic and ophiolitic provenance in the Northern Apennines, Italy: Chemical Geology, v. 122, p. 1-20.

VAN DER PLAS, L., AND TOBI, A.C., 1965, A chart for judging the reliability of point counting results: American Journal of Science, v. 263, p. 87-90.

von EynatTen, H., 1996, Provenanzanalyse kretazischer Siliziklastika aus den Nördlichen Kalkalpen: Petrographie, Mineralchemie und Geochronologie des frühalpidisch umgelagerten Detritus [unpublished Doctoral Thesis]: Mainz, University of Mainz, $145 \mathrm{p}$.

von Eynatten, H., and Gaupp, R., 1999, Provenance of Cretaceous synorogenic sandstones in the Eastern Alps: constraints from framework petrography, heavy mineral analysis, and mineral chemistry: Sedimentary Geology, v. 124, p. 81-111.

von Eynatten, H., Gaupp, R., And WiJbrans, J.R., 1996, ${ }^{40} \mathrm{Ar} /{ }^{39} \mathrm{Ar}$ laser-probe dating of detrita white micas from Cretaceous sedimentary rocks of the Eastern Alps: evidence for Variscan high-pressure metamorphism and implications for Alpine orogeny: Geology, v. 24, p. 691694.

von Eynatten, H., Gaupp, R., And Wijbrans, J.R., 1997, ${ }^{40} \mathrm{Ar} /{ }^{39} \mathrm{Ar}$ laserprobe dating of detrita white micas from Cretaceous sediments of the Eastern Alps: Evidence for Variscan highpressure metamorphism and implications for Alpine orogeny: Comment and Reply: Geology, v. 25 , p. $765-767$.

von Eynatten, H., Schlunegger, F., Gaupp, R., and Wijbrans, J.R., 1999, Exhumation of the Central Alps: evidence from ${ }^{40} \mathrm{Ar} /{ }^{39} \mathrm{Ar}$ laserprobe dating of detrital white micas from the Swiss Molasse Basin: Terra Nova, v. 11, p. 284-289.

Weltje, G.J., van Ansenwoude, S.O.K.J., AND DE Boer, P.L., 1996, High-frequency detrital signals in Eocene fan-delta sandstones of mixed parentage (south-central Pyrenees, Spain): a reconstruction of chemical weathering in transit: Journal of Sedimentary Research, v. 66 p. 119-131.

WoLf, K.H., 1971, Textural and compositional transitional stages between various lithic grain types (with a comment on "Interpreting detrital modes of graywacke and arkose"): Journal of Sedimentary Petrology, v. 41, p. 328-332.

ZuFfa, G.G., 1980, Hybrid arenites: their composition and classification: Journal of Sedimentary Petrology, v. 50, p. 21-29.

Received 20 November 2001, accepted 1 July 2002. 